\title{
Demographic and causal pattern of acute upper gastrointestinal bleeding in Mosul
}

\author{
Khaldoon Th. Al-Abachi \\ Department of Medicine, Nineveh College of Medicine, University of Mosul.
}

(Ann. Coll. Med. Mosul 2010; 36 (1 \& 2): 1-7).

Received: $29^{\text {th }}$ Jun 2009; Accepted: $9^{\text {th }}$ Jun 2010.

\begin{abstract}
Objectives: To assess the age and sex distribution of 200 patients presented with acute upper gastrointestinal bleeding (AUGIB) in Al-Salam General Hospital in Mosul, and to identify the causes of bleeding through endoscopic examination.

Patients and methods: This is a case series study of 200 patients with (AUGIB) at the endoscopy unit in Al-Salam general hospital in Mosul, during the period from April 1999 to January 2009. The endoscopic findings, causes of bleeding and the patients' age and gender were recorded, analysed and the results were compared with other similar studies.

Results: The mean age of the patients was $43.68 \pm 19.11$ years; those aged 60 years and above constituted 25.5\% (51/200). Male:female ratio was 2:1 (135 male, 65 female). Gastroduodenitis with erosions and duodenal ulcer (DU) were the main causes of (AUGIB) constituting $42.5 \%$ and $30.5 \%$ respectively. Actively bleeding (DU) constituted $36.1 \%$ (22/61) while actively bleeding erosions constituted $16.5 \%(14 / 85)$ which is a significant difference $(p=0.008)$. Non-steroidal anti-inflammatory drugs (NSAIDs) were associated with bleeding in $9 \%$ of the cases $(18 / 200)$.

Conclusions: In this sample from Mosul city, (AUGIB) afflicted a relatively younger age group compared with western studies, while male: female ratio was nearly similar (2:1).

Gastroduodenitis with erosions dominated the causes of bleeding and (DU) came next in frequency, while (DU) is the main cause in most western studies. The results of this study coincide more with the results from some developing countries.
\end{abstract}

Keywords: Acute upper gastrointestinal bleeding, gastroduodenitis, non-steroidal anti-inflammatory drugs.

الأهداف: التعرف على عمر وجنس · · مريض مصابين بنزف حاد من أعلى القناة الهضمية تم فحصهم بو اسطة الناظور

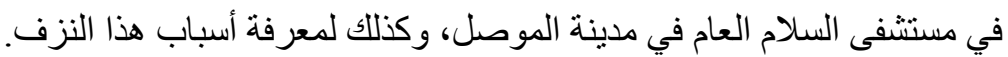
المرضى وطريقة البحث: تم در اسة حالات منسلسلة لمئتي مريض مصابين بنزف حاد من أعلى القناة الهضمية في وحدة

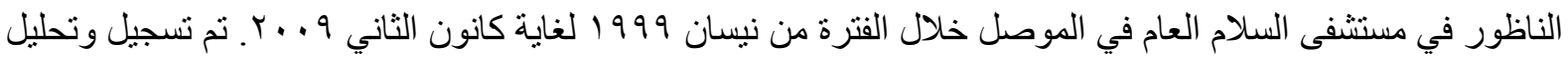
نتائج الفحص الناظوري و أسباب النزف و أعمار المرضى وجنسهم ومقارنة النتائج مع در اسات أخرى مشابهة.

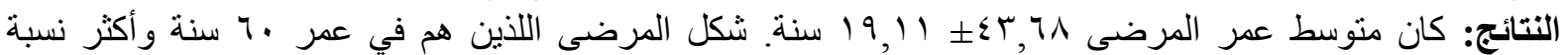

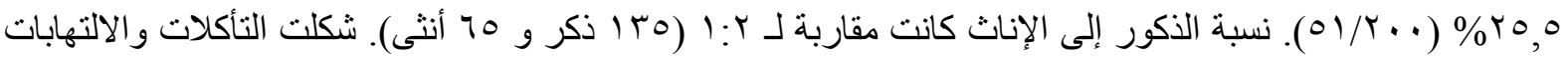

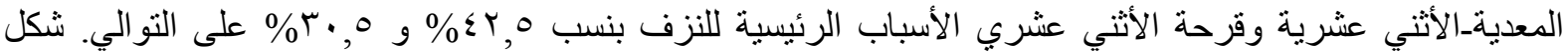

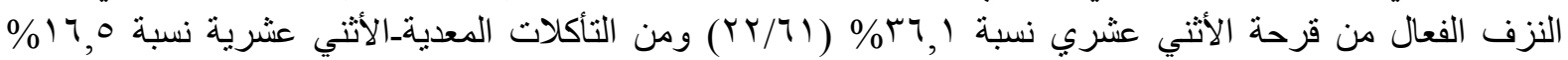




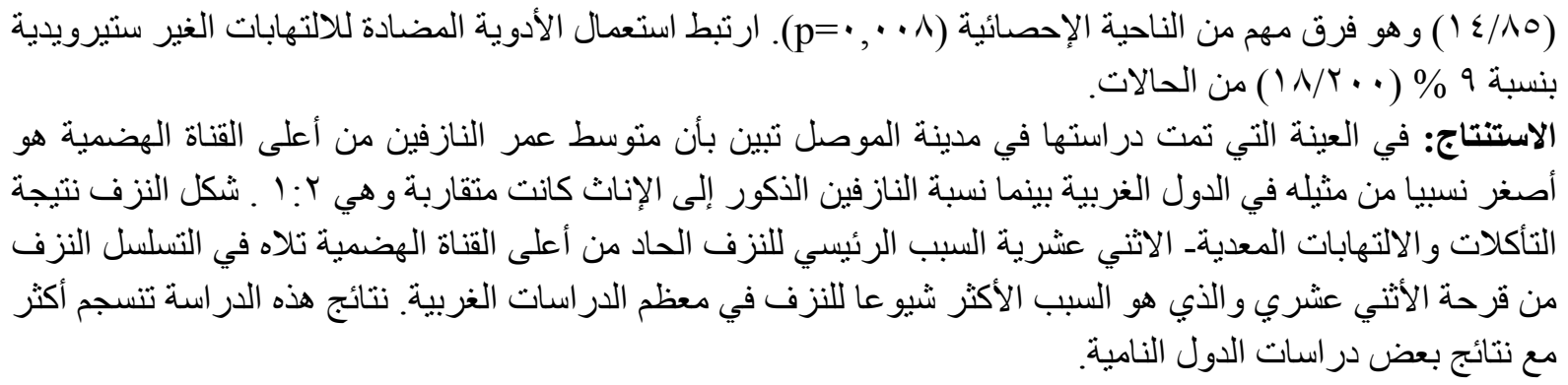

A cute upper gastrointestinal bleeding (AUGIB) is a common medical emergency that results in significant morbidity and mortality ${ }^{(1)}$. It is defined as gastrointestinal blood loss that originates proximal to the ligament of Treitz (2). Clinically (AUGIB) manifests as haematemesis and, or melaena and rarely haematochezia with or without haemodynamic compromise ${ }^{(3)}$. Endoscopy has a sensitivity of $92 \%$ for identification of the site of (AUGIB), with a specificity that approaches $100 \%{ }^{(4)}$, especially if it is done within the first 24 hour of (AUGIB) ${ }^{(5)}$. The age distribution varies depending on the studied population with significant frequency affecting the elderly population in the west ${ }^{(6,7)}$. The male:female ratio for (AUGIB) in some European countries and the United States is approximately $2: 1^{(8,9)}$. In the west, peptic ulcer is the most common cause of (AUGIB), accounting for up to $50 \%$ of cases ${ }^{(10)}$. Multiple studies showed variable contribution of gastroduodenal erosions (GDE) to (AUGIB) with a range of $(2-20 \%)^{(10,11,12)}$. Exposure to aspirin carries a definite risk of gastroduodenal injury ${ }^{(13)}$. Some $15-30 \%$ of patients exposed to (NSAIDs) develop gastroduodenal ulcers ${ }^{(14)}$, the risk of bleeding increases with older age (15)

There is regional variation regarding the frequency of causes of (AUGIB) depending on the demographic characteristics of the studied population, risk factors of bleeding, timing of the study and pathological classifications. In our region there is paucity of published reports about the epidemiology, demography, causes, and complications of upper gastrointestinal tract lesions.

The aim of this study is to elucidate the demographic features of (AUGIB) in a sample

of 200 patients from Mosul city, identifying its causes, and comparing our results with others.

\section{Patients and methods}

This study was conducted in the endoscopy unit of Al-Salam General Hospital in Mosul during the period from April 1999 to January 2009.

All patients presenting with haematemesis and, or melaena were included in this study. Two hundred patients were collected, most of the patients were referred from the casualty department and inpatient wards after receiving proper resuscitation, others were referred from outpatient or private clinics and they were haemodynamically stable. Informed Consent was taken from all patients or their families. Some patients were in a fasting state while others have recently vomited their stomach contents. The following data were obtained from every patient and registered on a usual form of endoscopic examination which included age, gender, date, site of referral, short relevant history and intake of medications. The endoscopic findings were documented on the same form including biopsies of suspicious lesions. The tools of diagnosis were Japanese Olympus GIF endoscope type XP40 (1999) and Olympus endoscope with videoscope GIF SP-20 (2007). All patients underwent endoscopic examination within the first 2-48 hours of admission. Patients with significant bleeding were supported with nasogastric tube suction prior to endoscopy. The diagnosis was based on endoscopic criteria of each lesion. Gastroduodenitis and (GDE) implied the presence of different grades of mucosal congestion and oedema in different patterns with or without visible erosions; such lesions 
might be confined to the stomach and or the duodenum. Signs of bleeding included actively bleeding lesion, lesion covered by blood clot, visible blood vessel at ulcer base, and presence of fresh blood or coffee ground material inside the stomach.

\section{Statistical analysis}

Data analysis was done by Minitab statistical soft ware program version 13.20. Descriptive statistics were used to describe the mean age of the sample. T-test unpaired two means and Z-two proportion were also applied. Statistical significance was set at $5 \%$.

\section{Results}

The patients' age range was 6-92 year. The mean age was around 43 year for males, females, and collectively.

Patients who were 60 year or above formed $25.5 \%$ of the group under study. The mean age of patients with (AUGIB) due to (NSAIDs) use was significantly higher than all other patients (57.9 year Vs 42.3 year, $p=0.001$ ). Male:female ratio (135:65) was $\sim 2: 1$ (table 1).

Gastroduodenitis and (GDE) constituted $42.5 \%(85 / 200)$ and was the main cause of (AUGIB), followed by (DU) with frequency of $30.5 \%(61 / 200)$ (table 2).

Actively bleeding (DU) formed $36.1 \%$ (22/61) while actively bleeding (GDE) formed $16.5 \%$ $(14 / 85)$, with significant difference between both frequencies $(p=0.008)$ (table 3 ).

Six patients of bleeding due to tumours were detected, five cases with adenocarcinoma of the stomach and one case of cancer invading the duodenum. We encountered a 15-year-old female with measles having extensive (GDE). Low dose aspirin and other (NSAIDs) were associated with $9 \%(18 / 200)$ of (AUGIB), erosions were the main lesions in $(72.2 \%$, 13/18) while associated duodenal ulcers formed $22.2 \%$ of the patients (4/18) and one patient showed no lesion $(5.6 \%, 1 / 18)$. Warfarin use was associated with only three patients of (AUGIB). One patient developed (AUGIB) due to gastroduodenitis after oral corticosteroids. Alcohol consumption was associated with (MWT) in one patient and with (GDE) in another.
Table (1): Age and sex distribution of 200 patients with (AUGIB).

\begin{tabular}{|l|c|c|}
\hline $\begin{array}{c}\text { Age group } \\
\text { (year) }\end{array}$ & Males & Females \\
\hline $0-9$ & 2 & 0 \\
\hline $10-19$ & 7 & 7 \\
\hline $20-29$ & 22 & 13 \\
\hline $30-39$ & 27 & 12 \\
\hline $40-49$ & 24 & 4 \\
\hline $50-59$ & 19 & 12 \\
\hline $60-69$ & 15 & 8 \\
\hline $70-79$ & 15 & 7 \\
\hline $80-89$ & 4 & 1 \\
\hline $90-99$ & 0 & 1 \\
\hline Total & 135 & 65 \\
\hline
\end{tabular}

Table (2): Endoscopic findings and frequency of (AUGIB).

\begin{tabular}{|l|c|c|}
\hline \multicolumn{1}{|c|}{ Source of bleeding } & $\begin{array}{c}\text { Number of } \\
\text { patients } \\
\mathrm{n}=200\end{array}$ & $\begin{array}{c}\text { Frequency } \\
\%\end{array}$ \\
\hline $\begin{array}{l}\text { Gastroduodenitis and } \\
\text { (GDE) }\end{array}$ & 85 & 42.5 \\
\hline Duodenal ulcer & 61 & $\begin{array}{c}30.5 \\
(\mathrm{p}=0.001)^{*}\end{array}$ \\
\hline Oesophageal varices & 13 & 6.5 \\
\hline $\begin{array}{l}\text { Oesophagitis and } \\
\text { oesophageal erosions }\end{array}$ & 13 & 6.5 \\
\hline Tumours & 2 & 3 \\
\hline $\begin{array}{l}\text { Mallory-Weiss tear } \\
\text { (MWT) }\end{array}$ & 2 & 1 \\
\hline $\begin{array}{l}\text { Vascular } \\
\text { malformations }\end{array}$ & 3 & 1.5 \\
\hline $\begin{array}{l}\text { Source of Excess } \\
\text { bleeding unidentified }\end{array}$ & 15 & 7.5 \\
\hline Normal endoscopy & & 1 \\
\hline
\end{tabular}

* Z-two proportion (compared with frequency of GDE).

Table (3): State of (DU) and (GDE) with their frequencies.

\begin{tabular}{|l|c|c|c|}
\hline Lesion & $\begin{array}{c}\text { Active } \\
\text { bleeding }\end{array}$ & Blood clot & Clean base \\
\hline $\begin{array}{l}(\mathrm{DU}) \\
\mathrm{n}=61\end{array}$ & $22(36.1 \%)$ & $19(31.1 \%)$ & $20(32.8 \%)$ \\
\hline $\begin{array}{l}(\mathrm{GDE}) \\
\mathrm{n}=85\end{array}$ & $14(16.5 \%)$ & $6(7 \%)$ & $65(76.5 \%)$ \\
\hline
\end{tabular}




\section{Discussion}

\section{Age}

In this study The mean age was 43.7 year with $25.5 \%$ of the patients being over 60 year; similar or close results were reported from Kuwait, Turkey, Saudi Arabia, and Pakistan where majority of patients were under 60 year $(12,16-18)$. In Western studies the mean age was $>60$ year and those above 60 year made 50 $70 \%$ of the total ${ }^{(19-21)}$. In the developed countries the percentage of older patients suffering from (AUGIB) has been increasing rapidly over the last years; the main reasons are the increase in the life expectancy and the increased consumption of many drugs such as (NSAIDs) ${ }^{(7)}$. In the present study the mean age of those who bled while using low dose aspirin and other (NSAIDs) was significantly higher than the mean age of the rest of the sample ( 57.9 Vs 42.3 respectively $p=0.001$ ), this can be due to the higher prevalence of cardiovascular and rheumatological conditions in the elderly necessitating the use of such drugs. In our locality which is part of a developing country (AUGIB) afflicts younger age groups which may be explained on the basis of the following risk factors: higher prevalence of H.pylori infection starting from childhood period, increasing rate of smoking in youth, environmental stressors, nutrition, and probably infection by other pathogens.

\section{Gender}

The male: female ratio was $\sim 2: 1$ which is similar to the ratio of some European countries and the United States ${ }^{(8,9)}$. Worldwide male patients have higher prevalence.

\section{Causes of (AUGIB)}

The main causes of (AUGIB) are different throughout the world depending on variation in the risk factors present in the studied populations. In this study gastroduodenitis with erosions was the most frequently encountered lesion followed by (DU) making $42.5 \%$ and $30.5 \%$ respectively. Different studies showed that peptic ulcer disease was the main cause ${ }^{(10-12,16)}$ (table).

Table: Causes of (AUGIB), a comparative table.

\begin{tabular}{|c|c|c|c|c|c|c|}
\hline $\begin{array}{l}\text { Source of } \\
\text { bleeding }\end{array}$ & $\begin{array}{c}\text { Frequency\% } \\
\text { Mosul } \\
n=200\end{array}$ & $\begin{array}{c}\text { Frequency\% } \\
\text { Kuwait } \\
n=215^{(16)}\end{array}$ & $\begin{array}{c}\text { Frequency\% } \\
\text { Egypt } \\
\mathrm{n}=11567^{(22)}\end{array}$ & $\begin{array}{c}\text { Frequency } \% \\
\text { Turkey } \\
n=336^{(12)}\end{array}$ & $\begin{array}{c}\text { Frequency\% } \\
\text { Malaysia } \\
\mathrm{n}=1830^{(11)}\end{array}$ & $\begin{array}{c}\text { Frequency\% } \\
\text { West } \\
n>1000^{(4,10)}\end{array}$ \\
\hline Peptic ulcer & 30.5 & $\begin{array}{c}61.8 \\
(P=0.0001)^{*}\end{array}$ & 24.9 & $\begin{array}{c}48.2 \\
(p=0.0001)^{*}\end{array}$ & 64 & $31-59$ \\
\hline $\begin{array}{l}\text { Gastroduodenitis } \\
\text { with erosions }\end{array}$ & 42.5 & $\begin{array}{c}6.97 \\
(p=0.0001)^{*}\end{array}$ & 41.7 & $\begin{array}{c}9.3 \\
(p=0.0001)^{*}\end{array}$ & 16.5 & $2-20$ \\
\hline $\begin{array}{l}\text { Esophageal } \\
\text { varices }\end{array}$ & 6.5 & 23.7 & 53.3 & 22 & 6.4 & $5-20$ \\
\hline $\begin{array}{l}\text { Esophagitis and } \\
\text { esophageal } \\
\text { erosions }\end{array}$ & 6.5 & 21.5 & & & & $1-15$ \\
\hline Tumours & 3 & 1.39 & & 3.9 & 3.6 & $1-7$ \\
\hline Mallory-Weis tear & 1 & 2.3 & & & & $5-15$ \\
\hline $\begin{array}{l}\text { Vascular } \\
\text { malformations }\end{array}$ & 1 & 1.86 & & & & $0-7$ \\
\hline $\begin{array}{l}\text { Normal } \\
\text { endoscopy }\end{array}$ & 7.5 & & & & 9 & $8-14$ \\
\hline $\begin{array}{l}\text { Excess bleeding- } \\
\text { no source } \\
\text { identified }\end{array}$ & 1.5 & & & & & \\
\hline
\end{tabular}

${ }^{*}$ Compared with results of the present study (Z-two proportion). 
Two studies were done in Saudi Arabia and Egypt showed that oesophagogastric varices was the most frequent cause of (AUGIB) ${ }^{(17,22)}$. Another five studies from Egypt, Jordan, and Pakistan found that bleeding due to gastroduodenitis and acute gastric mucosal lesions was commoner than bleeding due to peptic ulcer ${ }^{(18,22-25)}$. More recent data suggest that the proportion of cases caused by peptic ulcer disease has declined. Peptic ulcers were responsible for only $21 \%$ of episodes of (AUGIB) among 7822 patients included in a national, United States database between 1999 and 2001, the most common cause was nonspecific mucosal abnormalities ${ }^{(26)}$. A big epidemiological study was done in Germany which found that the incidence of bleeding peptic ulcer among younger patients is decreasing due to improved medical treatment through eradication of H.pylori infection while such incidence is increasing in the elderly patients due to a higher intake of (NSAIDs) ${ }^{(27)}$. Over the last two decades, Mosul physicians are increasingly using H.pylori eradication regimens which may have an impact on lowering the incidence of bleeding (DU). H.pylori infection has been implicated as a risk factor of bleeding from peptic ulcer, whether the same factor is operating in bleeding from erosions is a matter that needs to be confirmed by further studies. (NSAIDs) is an established risk of bleeding from erosions and peptic ulcers. Other types of infection and stress may be operating in bleeding from mucosal erosions but more work is needed to unmask these adverse factors. In the present study bleeding benign gastric ulcer is not encountered, probably due to its low incidence compared to (DU) while in the western series it might account for up to $20 \%{ }^{(28)}$.

Actively bleeding (DU) is significantly more common than bleeding erosions $(36.1 \% \mathrm{Vs}$ $16.5 \%-p=0.008$ ) which might be attributed to more active arterial bleeding from (DU) compared with capillary oozing from erosions. Alcoholism, as a cause of (AUGIB), is rare in the current study due to religious and social restrictions; it is a more frequent cause in the west.

\section{Drugs and (AUGIB)}

Despite the limited number of patients with (AUGIB) due to the associated use of low dose aspirin and other (NSAIDs), the study showed that the use of such drugs was mainly associated with bleeding erosions (13/18, $72.2 \%$ ) compared with duodenal ulcer (4/18, $22.2 \%$ ). It is well recognized that (NSAIDs) use is associated with an increased risk of gastric or duodenal ulcer; antral erosions are present within 1 to 2 days in virtually all individuals taking (NSAIDs) ${ }^{(29,30)}$.

The gastrointestinal tract is the most common site of significant bleeding in patients receiving long-term oral anticoagulant therapy ${ }^{(31)}$.

This study has got its own limitations; the studied sample was relatively small over this long period which might be ascribed to security problems making most of the patients shift to other hospitals. The results of this study will be more precise if other city hospitals were involved.

\section{Conclusions}

In this sample of 200 patients from Mosul, (AUGIB) afflicted a relatively younger age group which is consistent with the mean age in developing countries, but the sex ratio (male:female 2:1) was similar to studies from western and developed countries. Gastroduodenitis with erosions and (DU) were major causes of (AUGIB) which differs from western studies but coincides with results from some developing countries.

Analytical studies on larger scales are needed to identify the causes of gastroduodenitis with erosions and to explain the rarity of bleeding gastric ulcers.

\section{Acknowledgement}

I would like to thank the medical endoscopy staff of Al-Salam general hospital for their assistance and express my gratitude to Dr. Bedoor AK. Al-Irhayim (Department of pathology, Mosul college of Medicine) and Dr. Humam Gh. Haj Zubeer (Department of Community Medicine, Mosul College of Medicine) for their valuable remarks. 


\section{References}

1. Rockall TA, Logan RFA, Devlin HB, Northfield TC. Incidence of and mortality from acute upper gastrointestinal haemorrhage in the United Kingdom. BMJ 1995; 311:222-6.

2. Fallah MA, Prakash C, Edmundowicz S . Acute gastrointestinal bleeding. Med Clin North Am 2000; 84(5):1183-208.

3. Palmer KR. British Society of Gastroenterology Endoscopy Committee. Non-variceal upper gastrointestinal haemorrhage: guidelines. Gut 20t 2:51 (supplement Iv): 1-6.

4. David J.Bjorkman, Gastrointestinal haemorrhage in: Arend, Armitage, Clemmons, Drazen, Griggs, LaRusso. Cecil Medicine, $33^{\text {rd }}$ edition USA; Saunders, 2008, p 978.

5. Thoeni et al. A critical look at the accuracy of endoscopy and double-contrast radiography of the upper gastrointestinal tract in patients with substantial UGI haemorrhage. Radiology 1980; 135: 305308.

6. Church NC, Palmer KR. Non-variceal gastrointestinal haemorrhage. In: Evidence-based Gastroenterology and Hepatology- McDonald JWD, Burroughs AK, Feagan BG, eds. (2004) $2^{\text {nd }}$ ed. Blackwell publications.139-159.

7. Pilotto A. Aging and upper gastrointestinal disorders. Best Pract Res Clin Gastroenterol 2004; 18 suppl: 73:81.

8. Meaden C, Makin AJ. Diagnosis and treatment of patients with gastrointestinal bleeding. Curr Anaesthesia Crit Care 2004; 15: 123-32.

9. Yavorski RT, Wong RK, Maydono C, Battin LS, Furnia A, Amundson DE. Analysis of 3294 case of upper gastrointestinal bleeding in military medical facilities. Am J Gastroenterol, Apr 1995; 90(4): 568-73.

10. Laine L. Gastrointestinal bleeding. In: Braunwald E, Fausi A, Kasper D, eds. Harrison's principles of internal medicine. $17^{\text {th }}$ edition. New York; McGraw-Hill; 2008: 257-258.
11. Cheng JLS, Gunn A, Menon J, Arokiasarny J, Ong P, Long SY, Oommen C, Damodaran A. Aetiology of Acute Upper Gastrointestinal Bleeding in East Malaysia. Med J Mal 2001; 56 (supp A) D31.

12. Sezgln O, Altintas E, Tombak A. Effects of seasonal variation on acute upper gastrointestinal bleeding and its aetiology. The Turkish Journal of Gastroenterology 2007; 18(3): 172-176.

13. Sorensen HT, Mellemkjaer L, Blot WJ et al. Risk of upper gastrointestinal bleeding associated with the use of low-dose aspirin. Am J Gastroenterol 2000; 95: 2218-2224.

14. Laine L. Approaches to non-steroidal antiinflammatory drug use in the high-risk patient. Gastroenterology 2001; 120:594606.

15. Hemandez Diaz $S$ et al. Association between non-steroidal anti-inflammatory drugs and upper gastrointestinal tract bleeding /perforation: an overview of epidemiologic studies published in 1990s. Arch Int Med 2000; 160:2093-9.

16. Khajah AY, Hassan F, Al-Kalaoui M, AlNakib B. Acute Upper Gastrointestinal Bleeding in Kuwait- 1995. Kuwait Medical Journal 2001; 33(2): 144-147.

17. Qari FA. Major Causes of Upper Gastrointestinal Bleeding at King Abdul Aziz University Hospital (Jeddah). Kuwait Medical Journal 2001; 33(2): 127-130.

18. Khurram M, Khaar HT, Hasan Z et al. A 12 years audit of upper gastrointestinal endoscopic procedures. Journal of the College of Physicians and SurgeonsPakistan 2003; 13(6): 321-324.

19. Konstantinos C Thomopoulos, Konstantinos $P$ Mimidis, George J Theocharis, Anthie G Gatopoulou, Georgios N Kartalis, Vassilik N Nikolopoulou.Acute upper Gastrointestinal bleeding in patients on long-term oral anticoagulant therapy. World J Gastroenterol 2005; 11(9): 1365-1368.

20. Kenneth R. McQuaid, Gastrointestinal disorder in: Stephen J. McPhee, Maxine A. Papudakis. Current medical diagnosis 
and treatment $47^{\text {th }}$ edition, New York, McGraw Hill 2008; 487- 488.

21. Van Leerdam ME et al. Acute upper gastrointestinal bleeding between 1993/1994 and 2000. Am J Gastroenterol 2003; 98: 1494-1499.

22. Gouda MK. Acute upper gastrointestinal bleeding in Kaser El-Aini gastrointestinal endoscopy unit in the last 10 years (19912000). Cairo University, MSc Thesis 9896, 2002.

23. Banisalamah AA, Mraiat ZM. Upper Gastrointestinal Bleeding in Irbid, Jordan. Rawal Med J Jul-Dec 2007; 32(2): 105-8.

24. Chaudhary AW, Tabassum HM, Chaudhary MA. Pattern of Upper gastrointestinal bleeding at Rahim Yar Khan. Ann King Edward Med Coll Jul-Sep 2005; 11(3): 282-3.

25. Khurram M, Javed S, Khaar HTB, Goraya F, Hasan Z. Endoscopic evaluation of 2484 patients with upper GI Hemorrhage. J Rawal Med Coll Dec 2003; 7(2):89-81.

26. Boonpongmanee S, Fleischer DE, Pezzullo JC, et al. The frequency of peptic ulcer as a cause of upper gastrointestinal bleeding is exaggerated. Gastrointest Endosc 2004;59:788.
27. Ohmann $\mathrm{CH}$, Imhof $\mathrm{M}$, Ruppert $\mathrm{CH}$, Janzik $\mathrm{U}$, Vogt $\mathrm{CH}$, Frieling $\mathrm{CH}$, et al. Time-trends in the epidemiology of peptic ulcer bleeding. Scandinavian Journal of Gastroenterology 2005; 40:914-920.

28. Guidelines for Non-variceal Upper Gastrointestinal Haemorrhage, British Society of Gastroenterology (2002).

29. O'Laughlin JC, Hoftiezer JW, Ivey KJ. Effect of aspirin on the human stomach in normals: endoscopic comparison of damage produced one hour, 24 hour, and 2 weeks after administration. Scand J Gastroenterol Suppl 1981; 67:211-4.

30. Larkai EN, Smith JL, Lidsky MD, Graham DY. Gastroduodenal mucosa and dyspeptic symptoms in arthritic patients during chronic NSAID use. Am J Gastroenterol 1987; 82:1153-8.

31. Choudri CP, Palmer KR. Acute gastrointestinal haemorrhage in patients treated with anticoagulant drugs. Gut 1995; 36:483- 484. 